Nicole Torka, Jan Kees Looise, Stefan Zagelmeyer

\title{
Ordinary Atypical Workers, Participation within the Firm and Innovation: A Theoretical Endeavor and Empirical Outlook
}

This paper offers a theoretical exploration and empirical outlook towards a triptych heretofore not properly investigated: atypical work (e.g., self-employed, agency workers, and workers with a fixed-term contract), participation within the firm, and innovation. How, it must be asked, can and will atypical workers contribute to innovation through participation within the firm or, from another angle, how can participation within the firm contribute to atypical workers willingness to express innovative behavior? For the answer researchers have to learn far more about two distinct groups of atypical workers: 'external knowledge workers' who are highly educated and explicitly hired for innovation, and 'ordinary atypical workers' who are neither highly educated nor hired for innovational purposes. For two reasons, the focus here is on the latter: we (1) presume and show, in contrast to what many scholars assume, that ordinary atypical workers can contribute to innovation in a direct and positive way, and (2) argue that participation within the firm is the key for these workers potential contribution to innovation.

Key words: atypical work, flexible labour, freelancers, fixed-term contracts, temp agency work, (direct and representative) participation within the firm, social and technical innovation

* Nicole Torka is Senior Research Fellow at the University of Twente, School of Management \& Governance, the Netherlands.

E-mail: n.torka@utwente.nl,nicoletorka@gmail.com.

Jan Kees Looise is Full Professor Human Resource Management at the University of Twente, School of Management \& Governance, the Netherlands.

Stefan Zagelmeyer is Professor of Economics and Human Resource Management at the International University Bad Honnef, Germany and Assistant Professor at the University of Twente, School of Management \& Governance, the Netherlands.

** Article received: December 3, 2010

Revised version accepted after double blind review: August 23, 2011.

management revue, 22(3), 221-239

ISSN (print) 0935-9915, ISSN (internet) 1861-9908
DOI 10.1688/1861-9908_mrev_2011_03_Torka

(C) Rainer Hampp Verlag, www.Hampp-Verlag.de 


\section{Introduction}

For those who have faith in scholars' premises and empirical evidence, it seems obvious to believe that many modern organizations are torn in two ways: they have to be lean and unique simultaneously (e.g., Bolwijn \& Kumpe, 1990; Michie \& Sheehan, 2003). Scholars refer to labor as a potential source of corporate obesity as well as originality, suggesting that organizations balance these market demands by fragmenting the internal labor market (e.g., Atkinson, 1984; Hunter et al., 1993).

To lose the costly drag of excess girth, numerous organizations shift entrepreneurial risks to assumed easy replaceable workers by eroding their 'typical' employment relationships. The consequent impact is that for these workers a secure 'lifelong' relationship with one organization, rooted in a permanent labor contract, is no longer routinely obvious (e.g., Beck, 1999; Boltanski \& Ciapello, 1999). In this line of thought, for organizations their so-called atypical workers (e.g., self-employed, fixedterm, and agency workers) are just another commodity that purely serves as a budget item subject to the exigencies of the all-important business cycle. In contrast, for uniqueness or innovativeness, organizations place their trust on their core 'human resources': highly educated employees with firm-specific capabilities and, consequently, a well-deserved permanent labor contract (e.g., Grant, 1991; Pavitt, 1991; Schuler \& Jackson, 1987).

Given these widespread thoughts, it is not surprising very few scholars' link atypical workers in a direct and positive way to innovation; or that those who do so almost exclusively refer to highly educated 'external knowledge workers' explicitly hired for this aim. Nevertheless, Torka (2003) and Zhou et al. (2011) show that 'ordinary atypical workers', those neither highly educated nor hired for innovational purposes, can contribute to innovation in a direct and positive way. In this paper, we argue that workers' direct and representative participation within the firm, a voice and (co-)decision making capacity (Bryson, 2004), is essential for these workers contributions to innovation.

Participation is an important predictor of innovation (e.g., Blume \& Gerstlberger, 2007; Schwarz-Kocher et al., 2011), but the way atypical work can add value is not yet integrated into this knowledge field. Or, from another angle, previous studies on atypical work and innovation neglect the effects of participation. Therefore, we here take up the challenge and provide a theoretical and conceptual framework for further research that focuses on ordinary atypical workers direct and positive contributions to innovation through participation within the firm.

This article is structured as follows. We first review the literature that ignores participation, but explicitly claims to contribute to the atypical work and innovation discussion. This attention is crucial: after all, insight into the current state of research provides knowledge about (opposing) assumptions, (contradictory) findings, and shortcomings; all ingredients for future empirical investigations and theoretical explorations to come. Next, we integrate participation within the firm into the atypical work and innovation link. We discuss the ways in which atypical workers direct and representative participation can contribute to innovation, as well as present the conditions for their participation. The article closes with an integrative overview of the triptych atypical work, participation within the firm, and innovation. 


\section{Atypical workers and innovation}

Scholars refer to technical innovation as important for organizations' competitive advantage: the improvement or introduction of products/services or processes new to the firm or the market (e.g., Damanpour, 1991; Freeman \& Perez, 1988). Improvements or simple adjustments refer to incremental innovations (also known as continuous improvement); fundamental changes that represent a break with or departure from existing practice refer to radical innovations (Dewar \& Dutton, 1986).

More recently, authors have begun to sketch the significance of social innovation: the introduction or improvement of organizational or human resource management policies and practices (e.g., Alasoini, 2009; Jones et al., 2010; Koski \& Järvensivu, 2010; Looise, 1996). Social innovation can affect technical innovation and vice versa, and both seem to positively influence firms' economic performance. Moreover, the latter can influence (investments in) both forms of innovation (e.g., Frick, 2002; Ichniowski et al., 1996, Antonioli et al., 2009).

The literature on the link between atypical work and innovation discloses it yields either negative or positive outcomes for technical innovation. Within the positive and the negative cluster a difference can be drawn between direct and indirect contributions (see figure 1). Therefore, the following review is arranged along these two dimensions: direct vs. indirect and negative vs. positive.

\section{Atypical work has a direct, negative influence on innovation}

Several scholars refer to permanent employees' positive emotional bond with their firm (i.e., affective organizational commitment) and their firm-specific capabilities being indispensable for innovation (e.g., Grant, 1991; Pavitt, 1991; Schuler \& Jackson, 1987). Thus, by implication, atypical workers miss the essential competences for innovation and their employment status discourages the vital affection. Discouragement points to two suggested causes: the nature of the relationship and the quality of atypical work.

Concerning the former, it has been assumed that atypical worker and organization have an impersonal short-term monetizable exchange centered deal insufficient to evoke the stable, sincere feelings towards the organization assumed to be inevitable for innovation (e.g., De Ruyter et al., 2008; Michie \& Sheehan, 2003). Quality refers to the atypical workers' inferior conditions: besides job insecurity, they receive less pay, training, and appealing job conditions than do typical workers (e.g., Nienhüser \& Matiaske, 2006). These features of the quality of work life influence commitment (e.g., Meyer et al., 2002), and the latter predicts innovation (e.g., Eisenberger et al., 1990).

Following this line of reasoning, the relationship between atypical work and innovation is direct and negative. Several studies support such a negative assumption, but are inconclusive about a direct or indirect impact (e.g., Beugelsdijk, 2008; Chadwick \& Capelli, 2002; Michie \& Sheehan, 2003). Storey et al. (2002) report on a direct, negative influence: if those regarded as directly responsible for innovation were themselves atypical workers, the degree of innovativeness was lower. 


\section{Atypical work has an indirect, negative influence on innovation}

The literature also points to a possible indirect negative influence of atypical work on innovation; namely, through undesired effects on the quality of typical workers work life, and consequently a declining state of mind and/or space to devote to invention. The presence of atypical workers might cause permanent employees to experience enhanced (perceptions of job insecurity and super alienation as well distraction from core tasks (e.g., Boyce et al., 2007; Kulkarni \& Ramamoorthy, 2005; Lee \& Frenkel, 2004). Referring to the latter, typical workers when confronted with large numbers of newly hired atypical workers report on massive investments in training and correcting mistakes. Expectedly, these typical workers complain about lacking time for core tasks (Torka, 2003) and therefore may miss an adequate work environment and muse for innovation.

\section{Atypical work has an indirect, positive influence on innovation}

The literature provides four basic arguments for indirect positive contributions of atypical work to innovation (e.g., Adams \& Brock, 1986; Atkinson, 1984). First, atypical work as a source of cost savings creates opportunities for financial investments in innovation. Altuzarra and Serrano (2010) found a positive relationship between the rate of temporary workers and investments in R\&D activities. Second, atypical work is an option to remove the burden of routine work from core employees, in so doing freeing core human resources for innovation (Storey et al., 2002). Third, atypical work can serve as a buffer to protect the job security of permanent staff (see above). Finally, atypical workers' presence might refresh those permanent employees' set of attitudes and habits that hamper innovation such as conservatism, organizational blindness and rigidity.

\section{Atypical work has a direct, positive influence on innovation}

Finally, several authors ascribe to atypical work a direct positive role for innovation: firms consciously hire highly qualified atypical workers (i.e., external knowledge workers) to bring in fresh ideas and best practices taken from other firms, reducing obstacles for innovation as well as filling identified knowledge gaps (e.g., Lepak \& Snell, 2002; Matusik \& Hill, 1998). There is considerable research supporting these assumptions (e.g., Arvantis, 2005; Gupta et al., 2009; Huang et al., 2009; Nesheim, 2003, Storey et al., 2002). Figure 1 visualizes the four viewpoints presented above.

\section{Explaining contradictory assumptions and findings}

How are we to explain these contradicting assumptions and findings? There is a growing body of research by Martínez-Sánchez et al. (2011), Zhou et al. (2011) and Torka (2003) suggesting that restricting observation to employment status (i.e., atypical work vs. typical work) delivers mainly superficial knowledge, and may leads to incorrect conclusions. Alternatively, it is argued that scholars need to gain insight about what is in the deal: what do organizations expect from (i.e., motives for using atypical work; e.g., Alewell \& Hauff, 2011) and/or offer to atypical workers (i.e., work life quality) (see also Tsui et al., 1997; Tsui \& Wu, 2005)? 
Figure 1: Arguments for atypical workers direct vs. indirect, positive vs. negative contributions to innovation

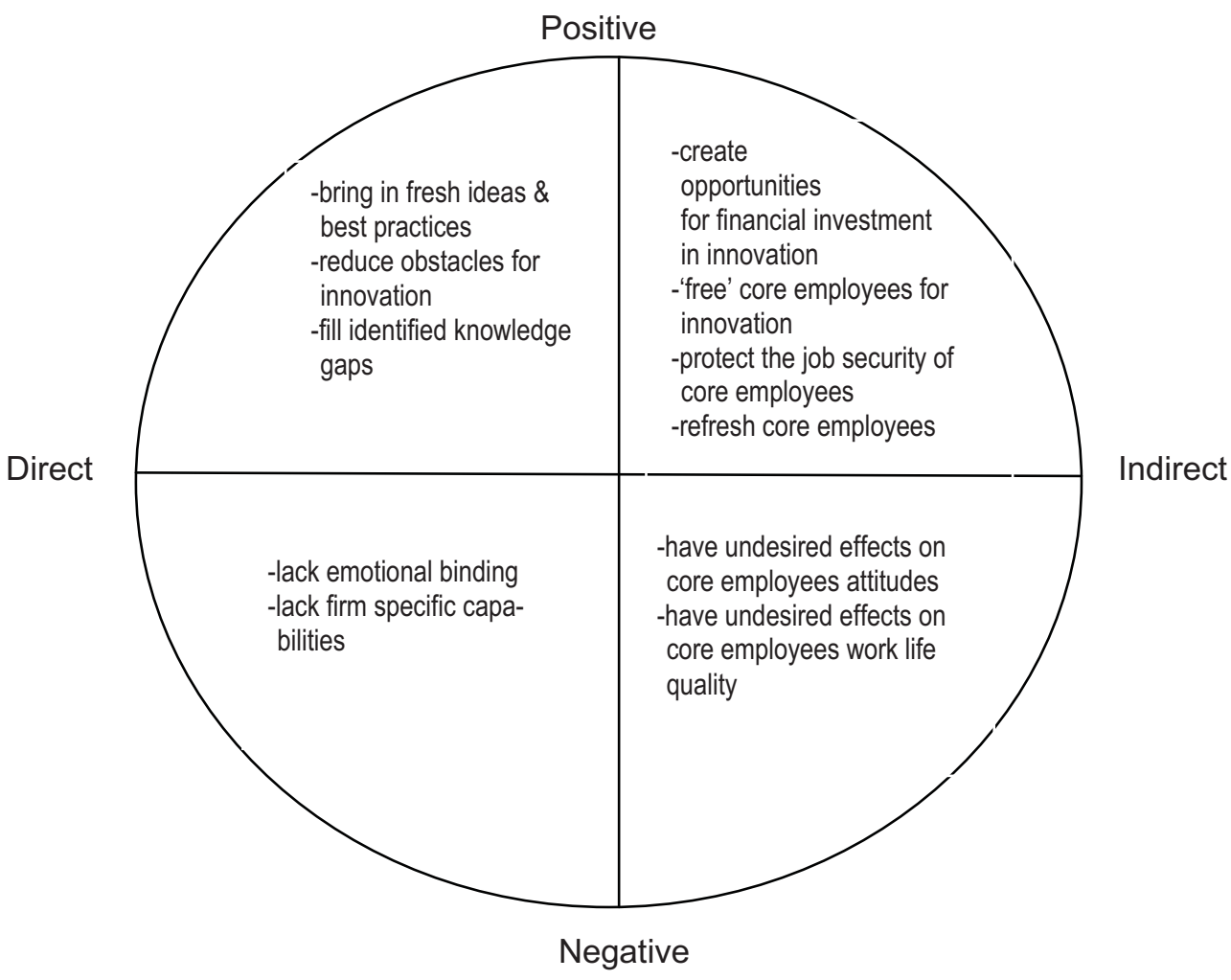

Martínez-Sánchez et al. (2011) found that external knowledge workers contribute to innovation positively, whereas agency workers and short-term hires do so negatively. The author's claim that "regarding the association between external flexibility and innovativeness, our research shows that it depends on the type of contingent employee" (p. 734); they link this assumption to organizations' different motives for atypical work. Thus, previous contradictory premises and findings can be explained by scholars' disregard of organizations expectations about atypical work. From this point of view external knowledge workers contribute to innovation simply because organizations explicitly expect them to do so: innovation is a mandatory part of their deal. In contrast, for ordinary atypical workers innovation lies outside their mandate: they are hired strictly to fulfill other matter of fact aims such as meeting fluctuations, replacing absentees, and reducing labor costs. So, by implication, Martínez-Sánchez et al. (2011) assume that atypical workers behavior depends on and is entirely fixed by mundane organizational expectations.

However, research suggests that ordinary atypical workers can exceed organizations' expectations by directly and positively contributing to innovation. Thus, the conclusions drawn by Martínez-Sánchez et al. (2011) might be invalid because in practice organizations' (prime) expectations do not appear to be all-decisive. Zhou et al. 
(2011) found that organizations with high percentages of workers on fixed-term contracts tend to have higher sales of imitative new products than organizations with low percentages of fixed-term workers, whereas the former perform significantly worse on sales of innovative new products than the latter. Analysis shows that screening personnel by the technique of initially only offering temporary contracts relates positively to incremental innovation. The authors explain atypical workers positive effect on imitative innovation by referring to this practice: organizations offer more than a shortterm, instrumental deal; in so doing they seem to take into account workers interest for job security.

It is essential to bear in mind that not all atypical workers want job security (e.g., Casey \& Alach, 2004; Torka \& Schyns, 2007). At least one study shows that ordinary atypical workers (i.e., metalworkers) without preferences for job security, and those with a preference for job security but without opportunities for permanent employment at the firm, can both directly and positively contribute to innovation: they share their renewing ideas with managers and colleagues or 'just' carry out improvements without the involvement of others (Torka, 2003). Communicating (on ideas) and deciding (to carry out improvements) refer to participation within the firm (e.g., Bryson, 2004; Marchington \& Wilkinson, 2000; Ramsay, 1991).

Innovation is just one feasible facet of participation. Consultation and (codecision making can also concern, for example, department issues or workers' interests. In the next section, we argue such general participation opportunities explain ordinary atypical workers' direct and positive communications over and decision making on innovation. Thus, participation might explain contradictory assumptions and outcomes concerning the normal everyday atypical work and innovation connection. However, previous studies on atypical work and innovation ignore these very basic potential effects of participation.

\section{Atypical workers and innovation: integrating participation within the firm}

Participation within the firm refers to direct participation (i.e., workers voice and (co-) decision making without the mediation of representatives; Bryson, 2004) and indirect or representative participation through works councils and alternative representation bodies not covered by law. Workers can participate through established mechanisms (e.g., works councils, alternative representation bodies not covered by law, problem-solving groups), or by spontaneous face-to-face communications with managers and colleagues: alternatively, they may also raise voice and (co-)decide without any invitation or involvement from others (e.g., Koski \& Järvensivu, 2010; Pyman et al., 2010; Salis \& Williams, 2010).

Innovation studies often neglect the role of participation (e.g., Blume \& Gerstlberger, 2007; Schwarz-Kocher et al., 2011), but some do show social and technical innovation benefit from direct and representative participation within the firm (e.g., Addison et al., 2007; Askildsen et al., 2006; Dilger, 2002; Jirjahn \& Kraft, 2011; Schwarz-Kocher et al., 2011; Stracke \& Nerdinger, 2010; Van het Kaar \& Looise, 1999). There seems to be a positive relationship between representative participation and direct participation (e.g., Helfen, 2005; Kleiner \& Lee, 1997). For example, Müller-Jentsch (2001) found that firms with a works council show more direct participation activities than firms without one. Thus, representative participation can influ- 
ence innovation not only directly, but also indirectly via its effect on direct participation.

In this section, we integrate participation into the atypical work and innovation connection. In so doing, we adapt general participation knowledge to atypical workers. We introduce the conditions or explanations for atypical workers participation by first discussing the several general paths by which atypical workers direct and representative participation can contribute to innovation. We also elaborate on recent relevant and significant knowledge gaps.

\section{Atypical work and innovation: participations contributions}

\section{Participations direct contributions to innovation}

Participation can contribute to innovation in two direct ways. First, as participants in direct participation and/or as representative body members (i.e., representatives) workers might suggest inventions (i.e., voice), co-decide on innovations or 'just' carry out innovations without prior involvement from management (i.e., decide). Second, as representatives workers might act as ‘shaping companion' (i.e., gestaltende Begleiter) by supporting management driven innovation. For example, through mediation between management and staff, convincing staff of the change necessity, unlocking shop-floor knowledge important for innovation, and guarding worker interests during the innovation process (Schwarz-Kocher et al., 2011, p. 123).

Ordinary atypical workers, those not highly educated and not hired for innovational purposes, can directly communicate innovative ideas to managers or colleagues, or implement improvements without consultation in advance (Torka, 2003). It can be assumed that when these workers communicate and (co-)decide on innovation this exceeds organizations (prime) expectations. Moreover, given many scholars' beliefs about what organizations (should) offer to such workers - a fair day's pay for a fair day's work -, some (e.g., Rousseau, 1995; Tsui \& Wu, 2005) would go so far as to claim encouraging participation opportunities for ordinary atypical workers goes beyond organizations' obligations (i.e., what they have to do for these workers).

In contrast, highly educated external knowledge workers have to directly share ideas, raise voice and/or (co-)decide on innovation: participation on innovation is an integral, self-evident element of their function, of their deal. For them it is downright frivolous (a) to consider the participation topic 'innovation' as something extraordinary or unexpected; (b) to investigate the conditions for participation (see next section); and (c) to treat, in general, participation within the firm as an independent variable, an autonomous measure of additional value, for understanding the substance of atypical work and the innovation relationship. Consequently, we argue that participation within the firm is merely 'the link' between ordinary atypical workers and innovation.

So, besides the fact that ordinary atypical workers can communicate or (co)decide on innovation, what insights are there in the archives of social science, about direct and representative participations direct contributions to innovation in relation to these workers? A careful search reveals the dire truth -- almost none at all. Research on atypical workers direct contributions to innovation as representatives, their 
possible role as 'shaping companion' and conditions for communicating about or executing innovations is entirely absent, as are investigations that penetrate the real contributions: what kind of improvements or introductions do these workers suggest, (co-)decide on or carry out ('concrete' social or technical innovations)?

Moreover, heretofore atypical work and participation within the firm have been essentially two disconnected research domains. Some scholars concentrate on the unionization of atypical workers and unions' efforts and strategies to recruit them (e.g., Aust \& Holz, 2006; Francesconi \& Garcia-Serrano, 2004; Pernicka \& Aust, 2007). However, the vast and heavily walked over topic of union participation lies outside the chief concern of this article. After all, in many continental European countries (e.g., Germany, the Netherlands) unions interfere mainly on the industry or national level, and bargain on conditions of employment and especially pay and benefits. Decision making in regard to individual organizations policies and practices that seem to stimulate innovation such as direct participation, training-on-the-job, and internal mobility essentially do not enter into the union mandate. It is well understood that unions and union participation cannot directly influence firm's innovation capacity (e.g., Looise et al., 2011).

\section{Participations indirect contributions to innovation}

Participation can contribute to innovation in three indirect ways. First, workers participation can have an unintended consequence, leading to decisions and reconsiderations on economic and organizational issues that ultimately contribute to innovation. For example, workers might recommend new workers who, once in the firm, seem to show innovative behavior; they may communicate about cheaper material where organizations that exploit this knowledge reduce costs and reinvest the savings in $\mathrm{R} \& \mathrm{D}$ activities; or as representatives they can initiate proposals for co-operation with other companies which once established can push innovation (e.g., Looise et al., 2011; Van het Kaar \& Looise, 1999).

Second, participation opportunities suggest that management considers workers as stakeholders (Beer et al., 1984). This might lead to workers' positive judgments about the ethics of management, about their sympathy for and sincere trust in them. This would be reinforced by organizational agents who express commitment towards them. Workers perceive participation opportunities as a signal of 'received' commitment (Torka, 2011); it has been assumed the latter influences workers' affective organizational commitment (Eisenberger et al., 1986). In this expansion of our understanding of the interactive factors at work, it becomes patent that the sheer presence of direct and representative participation opportunities can foster this commitment (e.g., Cox et al., 2006; Purcell \& Georgiadis, 2006; Torka et al., 2010) and, consequently, stimulate innovational spirit (e.g., Eisenberger et al., 1990). Nevertheless, admittedly evidence based upon strong research about the relationship between participation, commitment, and innovation is painfully not abundant.

Third, when managers really listen, the quality of work life (e.g., job characteristics, safety, training opportunities) can be genuinely enhanced (Schwarz-Kocher et al., 2011), which positively influences workers' commitment (e.g., Meyer et al., 2002). 
Consequently, through participation the work environment can improve in ways that will trigger invention as more generally the attitudes beneficial for innovation.

This line of reasoning returns us to the 'atypical work and innovation' issue and the flock of scholars who have no doubt whatsoever that a positive emotional bond with the organization is indispensible for innovation. There is a long list of those who are quite certain such a bond -- because of the relationship nature and the inferior quality of work - is impossible for atypical workers (e.g., De Ruyter et al., 2008; Grant, 1991; Pavitt, 1991; Schuler \& Jackson, 1987; Michie \& Sheehan, 2003). There are three fundamental reasons such a proposition is not only flawed, but untenable.

First, for 'own' and external knowledge workers' innovation is a part of the deal with the organization: they 'have to' contribute to innovation, and this refers to instrumental commitment rather than positive emotions. Instrumental commitment might also help explain innovative behavior of some ordinary atypical workers: those who want job security may express such behavior for convincing managers they are 'permanent contract worthy'. Moreover, research suggests affective organizational commitment is not necessary for desired behavior: for example, Wallace (1997) found that motivation does not correlate significantly with the latter, but instead with affective occupational commitment.

Second, organizations can and sometimes do offer the same participation opportunities (including representative participation), just one aspect of work life quality, to atypical workers and typical workers alike, and these opportunities seem to stimulate affective organizational commitment (Torka, 2003). Third, several studies clearly show the affective commitment of ordinary atypical workers can be similar to those of typical workers (e.g., McDonald \& Makin, 2000; Pearce, 1993; Torka \& Schyns, 2010). This pattern can be interpreted as evidence that their general work life quality, an important predictor of commitment, is equal.

It is certainly wise to argue that among the multiple aspects of work life quality participation plays a central and special role, constituting a chief explanatory factor of these findings. When participation concerns worker issues, participation refers to workers (direct or representative) voice and (co-) decision making on matters they deal with directly. Only when managers take this voice seriously, i.e., grasp and accommodate workers' interests, will desired outcomes (e.g., commitment, innovative behavior) be achieved (e.g. Bryson, 2004; Bryson et al., 2006; Gollan, 2003). This suggests that both ordinary typical and atypical workers, before participating on innovation or other issues that exceed their personal interests, must first be satisfied with participation results related to their work life quality.

Torka's (2003) findings support this idea. She found that managers initially have listened to those ordinary atypical workers who showed innovative behavior. For example, when agency workers complained about their temp work agency salary, user firm managers negotiated with the agency. Several agency workers asked for different work and managers approved their appeal; in several cases at the request of workers firms (voluntarily partly or fully) paid for agency workers training, even for those without the prospect of a permanent contract. 
We are speaking about agency workers and other workers involved in a triangular employment relationship, a relationship between a worker, an employer and a user firm. Such workers can be involved in direct and representative participation in two organizations simultaneously, meaning through it they might directly contribute to innovation in two organizations. Research suggests both organizations are together responsible for ordinary atypical workers (non-)contributions to innovation: the work life quality offered by the employer can cause spill over effects for the user firm, and vice versa (e.g., Benson, 1998; Van Breugel et al., 2005). Thus, scholars' studies of workers connected to two organizations in terms of participation and innovation should look closely at precisely what each organization offers.

After this intensive description of the direct and indirect ways in which the participation of ordinary atypical workers could contribute to innovation - 'could' because to date research is very scarce -, we must now turn to a fundamental factor: the conditions for atypical workers participation.

\section{Conditions for atypical workers participation within the firm}

We contend that - in contrast to what many scholars think - ordinary atypical workers can directly and positively contribute to innovation, and that participation within the firm is the key to this behavior. We have delineated the ways in which their participation could contribute to innovation. To complete the picture one further knowledge gap needs to be filled: what are the conditions for ordinary atypical workers participation within the firm? We have to refer to general participation literature which suggests three condition categories can be identified: (1) environmental conditions, (2) organizational conditions, and (3) individual conditions.

\section{Environmental conditions}

Environmental conditions refer to institutional frameworks and societal norms and values. Institutional frameworks concern laws and regulations which tend to strongly determine representative participation covered by law (e.g., Addison et al., 2000; Streeck, 2001). For example, Dutch and German law prescribes conditions under which employees have the right to establish a works council and council's rights (e.g., Looise et al., 2011; Müller-Jentsch, 2008). It is widely understood that representative participation covered by law influences the paths to participation that are not covered by formal law (see section introduction). Therefore, it can be assumed that institutional frameworks indirectly influence the latter, via representative participation covered by law.

In this context, agency workers need special attention. The Agency Worker Directive of the European Parliament and of the Council (Directive 2008/104/EC) aims to introduce the 'equal treatment' principle for agency workers (and other atypical workers). However, despite the uniformity in the regulation differences between countries will remain. After all, the Directive's 'equal treatment' principle only covers basic working conditions such as pay and working time and is eerily silent on other aspects of work life quality such as job characteristics or participation. Thus, countries, agencies and user firms continue to remain sovereign about the treatment of atypical workers. 
In the Netherlands workers with a fixed-term contract can vote for and be elected members of the works council. Freelancers do not have any representative participation rights at the firm. However, the Dutch Law on Works Councils prescribes that under certain conditions (i.e., tenure) agency workers can be elected members of the temp work agency and user firm works council. In other countries, agency workers cannot be elected members of representative participation bodies covered by law, or only have this right at the temp work agency (e.g., Germany, Poland, Sweden). At the present time research about atypical workers in their role as representatives (in bodies covered or uncovered by law) is entirely missing.

For at least three basic reasons future (cross-national) research should take into account the institutional framework for atypical workers' participation and real presence in representative bodies. First, representative participation rights may signal to organizations, that for atypical workers, participation in general is a normal, desired and valuable thing. This might contribute to a positive participation climate (e.g., Deery \& Iverson, 2005; Pyman et al., 2010) for these workers and stimulates them to raise voice and (Co-)decide on their work life quality. Consequently, if and when managers start to listen, desired behavior is more likely. Thus, such formal participation rights may co-explain possible differences between countries concerning atypical workers work life quality, and consequently their attitudes and behaviors.

Second, atypical workers who serve as representatives might also express more direct voice and (co-) decision making behavior. Finally, atypical workers as representatives may serve as 'role models': they (implicitly) 'communicate' to other atypical and typical workers as well as skeptical managers that the formers' voice is desired. Such exemplarity can contribute to perceived feelings of 'corporate democracy' or nondiscrimination, a good participation climate, and related 'productive' outcomes.

We also assume that societal norms and values that are not routinized into laws and regulations influence participation behavior. In general, the cultural dimension which encompasses an infinite range of human action, such as power distance and individualism (Hofstede, 1980), might well explain a great deal about participation differences across countries. We suggest that atypical workers direct and representative participation can be influenced by the regional societal appreciation and position of atypical work. For example, in Germany, in sharp contrast to the Netherlands, the media and actors commenting on events and trends commonly refer to agency work (i.e., Leiharbeit or Zeitarbeit) as a form of 'modern slavery'. It is not impossible for such expressions to influence managers, typical workers and atypical workers perceptions of (the position of) atypical work in general, and consequently participation behavior. Thus, such societal convictions might co-explain why atypical workers in different countries may express varying attitudes, as well as in relation to typical workers. In sum, future studies on atypical work, participation, and innovation should take into account institutional frameworks and societal values when discussing results, especially when comparing atypical workers across countries.

\section{Organizational conditions}

Organizational conditions refer to three factors that can influence atypical workers direct and representative participation: (1) management support for participation, (2) appropriate participation 
policies and practices for participation and (3) work life quality. Not only innovation (e.g., Gemünden, 1985; Hauschildt \& Chakrabarti. 1989), but also participation within the firm needs supporters or promoters. The responsiveness of top management and direct supervisors to participation is crucial (Bryson, 2004) because both can promote or oppose participation (e.g., Bryson et al., 2006; Ellguth, 2005; Hauser-Dietz et al., 2006; Pyman et al., 2010). Moreover, those who guide participation (e.g., direct supervisors, representatives) need to get unambiguous support from management (e.g., time for implementation, training) to fulfill this role adequately (e.g., Cunningham \& Hyman, 1999; Fenton-O’Creevy, 2001; Torka et al., 2008).

Peirce et al. (1998) emphasize the importance of well-written participation policies and clear practices. These should take into account the subject matter (i.e., from trivial to strategic matters and concerns), degree (i.e., extent of influence), level (i.e., top-down information flow, consultation or decision-making) and form of participation (i.e., worker, department, establishment or corporate level) (e.g., Marchington \& Wilkinson, 2005, Ramsay, 1991). Moreover, to prevent dissatisfaction among workers about participation, it has to be made clear if and when they should expect feedback on their contributions (Torka, 2003).

Dissatisfaction and satisfaction with work life quality (e.g., pay, training opportunities, job characteristics) determine if workers raise voice and (co-)decide (e.g., Charlwood, 2002, Hirschman, 1970), and successful participation strongly influences work life quality. Thus, work life quality and participation reinforce each other. Again, we assume that managers must first to listen to workers interests and satisfy their needs, before the latter are willing to participate on issues that exceed their personal needs such as local department affairs and innovation.

It can be assumed that management support and appropriate policies and practices for participation determine not only the incidence of participation (e.g., presence or absence, amount), but also the perceived quality of participation. Participation quality refers to workers' satisfaction with and perceived (distributive and procedural) fairness of participation. These notions seem to influence affective organizational commitment (Torka et al., 2010) and therefore behavior.

All three organizational conditions influence typical and atypical workers direct and representative (non-)participation. Moreover, differences between typical and atypical workers concerning these conditions might explain differences in participation and related attitudes and behaviors. Therefore, future research on atypical work, participation, and innovation should always take into account 'the equality' of organizational conditions.

\section{Individual conditions}

Finally, it is also the case that workers individual characteristics and personality seem to influence participation. Studies show that the following individual characteristics are related to direct and representative participation (i.e., membership in representative bodies): age, gender, tenure, educational level, job level, participation experience, leftwing views, instrumentality (i.e., participation for rational, calculated motives), and collective versus individualistic orientation (e.g., Behrens, 2009; Furåker \& Berglund, 2003; Hyman, 1992; Pernicka, 2006; Strömer, 2010). 
Up to now there have been very few studies that explore the relationships between personality (e.g., Big Five, self-efficacy, risk aversion, perceived locus of control) and participation, but there is slight archival evidence that personality predicts workers' direct and representative participation (Avery, 2003; LePine \& Van Dyne, 2001; Nikolaou et al., 2008; Strömer, 2010). Thus, future research on atypical workers participation should include or at least control for individual parameters. This advice is reinforced by the fact that a number of studies show that atypical workers (like permanent employees) are not a homogenous group: In the real world of labor flowing across national and regional boundaries, they differ concerning their (contract) preferences, individual characteristics, education, skills and so on (e.g., De Cuyper et al., 2008). Translated to participation, this means that individual conditions might be equally or more important for explaining participation behavior than the employment status.

After this description of conditions for atypical and typical workers' direct and representative participation, and presenting knowledge on the relationships between the core variables central to this article, let's proceed to summarize our (simplified) conceptual model that can guide future research on the triptych atypical work, participation within the firm and innovation:

Figure 2: Conceptual model explaining the connections between participation within the firm and innovation for (atypical and typical) ordinary workers

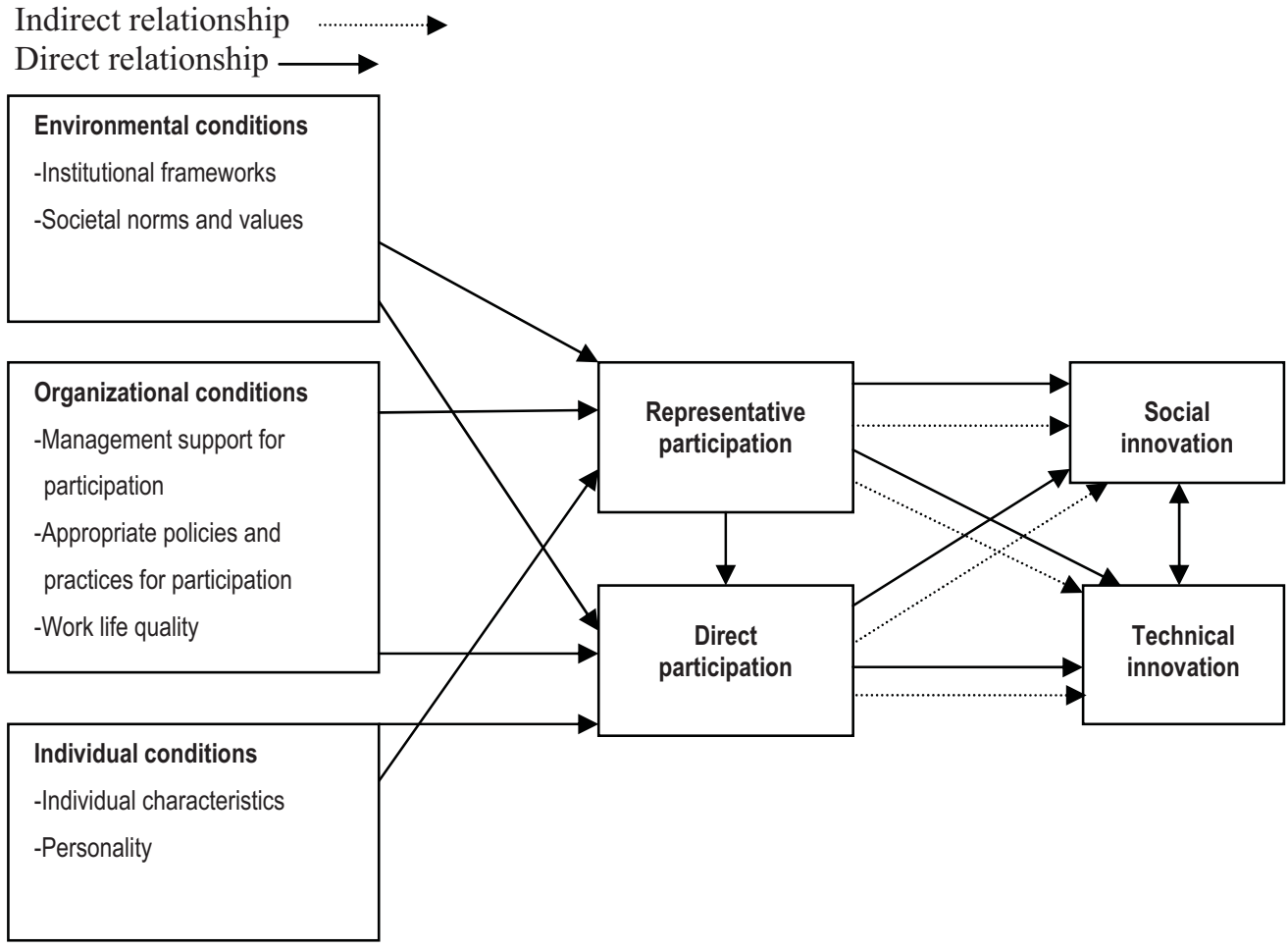




\section{Conclusion}

The aim of this article was to provide a theoretical and conceptual framework that might be fruitful in further research about a current frontier of knowledge: ordinary atypical workers (i.e., not highly educated or hired for innovational purposes) direct and positive contributions to innovation through participation within the firm. We stressed the weak state of current research on atypical work and innovation, and offered an outline of the direct and indirect ways in which atypical workers can contribute to innovation, and the conditions for atypical workers direct and representative participation.

Not only is research on the triptych missing, but many of the studies that there are on atypical work and innovation ignore, besides the effects of participation, organizations expectations and offers to atypical workers. It is a glaring fact that atypical workers are a neglected group in investigations on participation within the firm. However, we assume that we have made a persuasive case that participation within the firm is decisive for ordinary atypical workers' unexpected and extraordinary contributions to innovation. Moreover, we were able to show that several widespread assumptions about (the position of) atypical workers are not per se true: organizations do not necessarily treat ordinary atypical workers as a 'second class commodity' or fragment the internal labor market into inferior and superior labor segments. They can and should offer these workers a work life quality equal to those of permanent employees so they can develop the same levels of satisfaction with work life, desired attitudes and behaviors.

Given the importance of participation within the firm for workers (e.g., work life quality, well-being) and organizations' innovation capacity, further research zooming-in on atypical workers seems very appropriate. This research should anticipate on two obstacles researchers on participation and/or innovation have already mentioned.

First, investigators should overcome a pure "dummy variable approach" (Addison et al., 2004; p. 227-278). This means the exclusive focus on the presence or absence and/or the amount of participation and innovation. Instead, researchers should also pay attention to the participation quality and content as well as the substance of the ordinary atypical workers concrete contributions' to social and technical innovation: what kinds of improvements or introductions do these workers suggest, (co-)decide on or carry out?

Second, many participation and innovation researchers seem to choose a one-sided view. They exclusively focus, for example, on either the firm-level, a management perspective or on workers' perceptions. However, in order to achieve a deeper understanding, research on the triptych should pay attention to divergent evidence, behaviors, interests, perceptions, and roles related to different organizational actors (e.g., top-managers, line-managers, representation body members, subordinates) (e.g., Gemünden, 1985; Hauschildt \& Chakrabarti. 1989; Koski \& Järvensivu, 2010).

Researchers engaged in participation and/or innovation issues are fully cognizant of these current problems and the incompleteness we have sketched in the core of this paper, and recommend overcoming them with case study research (e.g., Addison et al., 2004; Blume \& Gerstlberger, 2007; Frick, 2008; Pyman et al., 2010). We urge such 
projects begin with intense explorative, qualitative research. The use of (pilot-) interviews is an invaluable method since it is unclear whether the presented framework of participation predictors is exhaustive, and the number of actors within the cases is large enough for questionnaire research. Further, in general researchers should garner the wealth of common sense insight available to participants about the current black box' of the triptych employment relationships, worker participation within the firm, and innovation. Therefore, only after investigators have really listened to the voice of actors, about "what is really going on", can questionnaire research be used to test the assumed relationships.

\section{References}

Adams, W., \& Brock, J. (1986). The bigness complex: Industry, labor and government in the American economy, New York: Pantheon.

Addison, J.T., Schank, T., Schnabel, C., \& Wagner, J. (2007). Do Works Councils Inhibit Investment? Industrial and Labor Relations Review, 60, 187-203.

Addison, J.T., Schnabel, C., \& Wagner, J. (2004). The course of research into the economic consequences of German works councils. British Journal of Industrial Relations, 42, 255-281.

Addison, J.T., Siebert, W.S., Wagner, J., \& Wei, X. (2000). Worker participation and firm performance: Evidence from Germany and Britain. British Journal of Industrial Relations, 38, 7-48.

Alasoini, T. (2009). Strategies to promote workplace innovation: A comparative analysis of nine national and regional approaches. Economic and Industrial Democracy, 30, 614-642.

Alewell, D., \& Hauff, S. (2011). Make-or-buy decisions regarding temporary agency work - an empirical analysis of the decision process and expected effects. International Journal of Human Resource Management, 22, 1-19.

Altuzarra, A., \& Serrano, F. (2010). Firms' innovation activity and numerical flexibility. Industrial and Labor Relations Review, 63, 327-339.

Antonioli, D., Mazzanti, M., \& Pini, P. (2009). Innovation, working conditions and industrial relations: Evidence for a local production system. Economic and Industrial Democracy, 30, 157-181.

Arvanitis, S. (2005). Modes of labor flexibility at firm level: are there any implications for performance and innovation? Evidence for the Swiss economy. Industrial and Corporate Change, 14, 993-1016.

Askildsen, J.E., Jirjahn, U., \& Smith, S.C. (2006). Works councils and environmental investment: Theory and evidence form German panel data. Journal of Economic Behavior and Organization, 60, 346-372.

Atkinson, J. (1984). The Flexible Firm and the Shape of Jobs to Come. Labour Market Issues No. 5. Oxford: Ruskin College Oxford.

Aust, A., \& Holz, H. (2006). Von der Ignoranz zur Organisierung? Gewerkschaftliche Strategien im Umgang mit atypisch Beschäftigten am Beispiel von Callcentern und Leiharbeit. Industrielle Beziehungen, 13, 291-313.

Avery, D.R. (2003). Personality as a predictor of the value of voice. Journal of Psychology, 137, 435-446.

Beck, U. (1999). Scböne neue Arbeitswelt. Vision: Weltbürgergesellschaft. Frankfurt am Main: Campus.

Beer, M., Spector, B., Lawrence, P.R., Quinn Mills, D., \& Walton, R.E. (1984). Managing Human Assets. New York: Free Press.

Behrens, M. (2009). Unterscheiden sich Mitglieder von Betriebs- und Personalräten vom Rest der Belegschaften? Industrielle Beriehungen, 16, 303-326.

Benson, J. (1998). Dual commitment: contract workers in Australian manufacturing enterprises. Journal of Management Studies, 35, 355-75.

Beugelsdijk, S. (2008). Strategic human resource practices and product innovation.Organization Studies, 29, 821-847.

Blume, L., \& Gerstlberger, W. (2007). Determinanten betrieblicher Innovation: Partizipation von Beschäftigten als vernachlässigter Einflussfaktor. Industrielle Beziehungen, 14, 223-244. 
Boltanski, L., \& Ciapello, E. (1999). Le nouvel esprit du capitalism. Paris: Gallimard.

Bolwijn, P.T., \& Kumpe, T. (1990). Manufacturing in the 1990s - Productivity, flexibility and innovation. Long Range Planning, 23, 44-57.

Boyce, A., Ryan, A., Jonus, A., \& Morgeson, F. (2007). Temporary worker, permanent loser? A model of the stigmatisation of temporary workers. Journal of Management, 33, 5-29.

Bryson, A. (2004). Managerial responsiveness to union and nonunion worker voice in Britain. Industrial Relations, 43, 213-241.

Bryson, A., Charlwood, A., \& Forth J. (2006). Worker voice, managerial response and labour productivity: an empirical investigation. Industrial Relations Journal, 37, 438-455.

Casey, C., \& Alach, P. (2004). Just a temp? Women, temporary employment and lifestyle. Work, Employment and Society, 18, 459-480.

Chadwick, C., \& Capelli, P. (2002). Functional or numerical flexibility? Which pays off for organizations? Management Department, The Wharton School, University of Pennsylvania.

Charlwood, A. (2002). Why do non-union employees want to unionize? Evidence from Britain. British Journal of Industrial Relations, 40, 463-491.

Cox, A., Zagelmeyer, S., \& Marchington, M. (2006). Embedding employee involvement and participation at work. Human Resource Management Journal, 16, 250-267.

Cunningham, I., \& Hyman, J. (1999). The Poverty of Empowerment? A Critical Case Study. Personnel Review, 28, 192-207.

Damanpour, F. (1991). Organizational innovation: A meta-analysis of effects of determinants and moderators. Academy of Management Journal, 34, 555-590.

De Cuyper, N., De Jong, J., De Witte, H., Isaksson, K., Rigotti, T., \& Schalk, R. (2008). Literature review of theory and research on the psychological impact of temporary employment: Towards a conceptual model. International Journal of Management Reviews, 10, 25-51

Deery, S.J., \& Iverson, R.D. (2005). Labor-management cooperation: Antecedents and impact on organizational performance. Industrial and Labor Relations Review, 58, 588-609.

De Ruyter, A., Kirkpatrick, I., Hoque, K., Lonsdale, C., \& Malan, J. (2008). Agency working and the degradation of public service employment: the case of nurses and social workers. International Journal of Human Resource Management, 19, 432-445.

Dewar, R.D., \& Dutton, J.E. (1986). The adoption of radical and incremental innovations: An empirical analysis. Management Science, 32, 1422-1433.

Dilger, A. (2002). Ökonomik betrieblicher Mitbestimmung. Die wirtschaftlichen Folgen von Betriebsräten. München/Mering: Rainer Hampp Verlag.

Eisenberger, R., Fasolo, P., \& Davis-MaMastro, V. (1990). Perceived organizational support and employee diligence, commitment, and innovation. Journal of Applied Psychology, 75, 51-59

Eisenberger, R., Huntington, R., Hutchinson, S., \& Sowa, D. (1986). Perceived organizational support. Journal of Applied Psychology, 71, 500-507.

Ellguth, P. (2005). Betriebe ohne Betriebsrat - welche Rolle spielen betriebsspezifische Formen der Mitarbeitervertretung? Industrielle Beriebungen, 12, 149-176.

Fenton-O'Creevy, M. (2001). Employee Involvement and the Middle Manager: Saboteur or Scapegoat? Human Resource Management Journal, 11, 24-40.

Francesconi, M., \& Garcia-Serrano, C. (2004). Unions and flexible employment in Britain and Spain: A descriptive note. Industrial Relations, 43, 874-882.

Freeman, C., \& Perez, C. (1988). Structural crisis of adjustment, business cycles and investment behaviour. In G. Dosi, C. Freeman, R. Nelson, G. Silverberg \& L. Soete (eds.), Technical change and economic theory (pp.38-66). London: Pinter Publishers Limited.

Frick, B. (2002). "High Performance Work Practices" und betriebliche Mitbestimmung: Komplementär oder substitutiv? Empirische Befunde für den deutschen Maschinenbau. Industrielle Beziehungen, 7 , 79-102.

Frick, B. (2008). Betriebliche Mitbestimmung unter Rechtfertigungsdruck. Die relative Bedeutung von Produktivitäts- und Umverteilungseffekten. Industrielle Beriebungen, 15, 164-177. 
Furåker, B., \& Berglund, T. (2003). Are the unions still needed? Employees' views of their relations to unions and employers. Economic and Industrial Democracy, 24, pp. 573-594.

Gemünden, H.G. (1985). 'Promoters' - Key persons for the development and marketing of innovative industrial products. In K. Backhaus \& D. Wilson (eds.), Industrial Marketing. A German-American Perspective pp. 134-166). Berlin: Springer.

Gollan, P.J. (2003). All talk but no voice: Employee voice at the Eurotunnel call centre. Economic and Industrial Democracy, 24, 509-541.

Grant, R. (1991). The resource-based theory of competitive advantage: Implications for strategy formation. California Management Review, 34, 114-135.

Gupta, S., Woodside, A., Dubelaar, C., \& Bradmore, D. (2009). Diffusing knowledge-based core competencies for leveraging process organizations (KPOs) in pharmaceutical networks. Industrial Marketing Management, 38, 219-27.

Hauschildt, J., \& Chakrabarti, A. (1989). Division of labour in innovation management. R\&D Management, 19, 161-171.

Hauser-Ditz, A., Hertwig, M., \& Pries, L. (2006). Betriebsräte und "andere Vertretungsorgane". Verbreitung und Kontext betrieblicher Beschäftigtenvertretungen in der deutschen Privatwirtschaft. Industrielle Beriebungen, 13, 340-369.

Helfen, M. (2005). De-Institutionalisierung des Betriebsrates. Welchen Erklärungsbeitrag liefern 'New Economy' und direkte Partizipation? Industrielle Beqiehungen, 12, 120-148.

Hirschman, A.O. (1970). Exit, voice and loyalty: Responses to decline in firms, organizations, and states. Cambridge, MA: Harvard University Press.

Hofstede, G. (1980). Culture's consequences: International differences in work-related values. Beverly Hills/London: Sage.

Huang, Y., Chung, H., \& Lin, C. (2009). R\&D sourcing strategies: determinants and consequences. Technovation, 29, 155-69.

Hunter, L., McGregor, A., MacInnes, J., \& Sproull, A. (1993). The 'flexible firm': Strategy and segmentation. British Journal of Industrial Relations, 31, 383-407.

Hyman, R. (1992). Trade unions and the disaggregation of the working class. In M. Regini (ed.), The future of labour movements (pp. 150-168). London: Sage.

Ichniowski, C., Kochan, T., Levine, D., Olson, O., \& Strauss, G. (1996). What works at work. Industrial Relations, 35, 299-333.

Jirjahn, U., \& Kraft, K. (2011). Do spillovers stimulate incremental or drastic product innovations? Hypotheses and evidence from German establishment data. Oxford Bulletin of Economics and Statistics, 73, 1-30.

Jones, D.C., Kalmi, P., \& Kauhanen, A. (2010). How does employee involvement stack up? The effects of human resource management policies on performance in a retail firm. Industrial Relations, 49, 1-21.

Kleiner, M.M., \& Lee, Y.-M. (1997). Work councils and unionization: Lessons from South Korea. Industrial Relations, 36, 1-16.

Koski, P., \& Järvensivu, A. (2010). The innovation diffusion paradox in the light of 'shop-floor games' and micro-politics. Economic and Industrial Democracy, 31, 345-363.

Kulkarni, S., \& Ramamoorthy, N. (2005). Commitment, flexibility and the choice of employment contracts. Human Relations, 58, 741-761.

Lee, B-H., \& Frenkel, S (2004). Fragmentation on the shop-floor: the case of regular and contract workers in a Korean auto company. Work, Employment \& Society, 18, 507-530.

Lepak, D., \& Snell, S. (2002). Examining the human resource architecture: the relationships among human capital, employment, and human resource configurations. Journal of Management, 28, 517-43.

LePine, J.A., \& Van Dyne, L. (2001). Voice and cooperative behavior as contrasting forms of contextual performance: evidence of differential relationships with Big Five personality characteristics and cognitive ability. Journal of Applied Psychology, 86, 326-336.

Looise, J.C. (1996). Sociale innovatie moet, maar hoe? Enschede, Universiteit Twente. 
Looise, J.C., Torka, N., \& Wigboldus, J.E. (2011). Understanding the link between worker participation and organizational performance. Advances in Industrial and Labor Relations, 18, 87-113.

McDonald, D.J., \& Makin, P.J. (2000). The psychological contract, organisational commitment and job satisfaction of temporary staff. Leadership and Organization Development Journal, 21, 84-91.

Marchington, M., \& Wilkinson, A. (2000). Direct participation. In S. Bach \& K. Sisson (eds.), Personnel Management (pp. 340-364). Oxford: Blackwell.

Martínez-Sánchez, A., Vela-Jiménez, M.-J., Pérez-Pérez, M., \& de Luis-Carnicer, P. (2011). The dynamics of labour flexibility: Relationships between employment type and innovativeness. Journal of Management Studies, 48, 715-736.

Matusik, S.F., \& Hill, C.W.L. (1998). The utilization of contingent work, knowledge creation, and competitive advantage. The Academy of Management Review, 23, 680-697.

Meyer, J.P., Stanley, D.J., Herscovitch, L., \& Topolnytsky, L. (2002). Affective, continuance, and normative commitment to the organization: A meta-analysis of antecedents, correlates, and consequences. Journal of Vocational Behavior, 61, 20-52.

Michie, J., \& Sheehan, M. (2003). Labour market deregulation, 'flexibility' and innovation. Cambridge Journal of Economics, 27, 123-143.

Müller-Jentsch, W. (2001). Works councils and HRM in Germany: Analytical arguments and empirical evidence. In R. Markey, P. Gollan, A. Hodgkinson, A. Chouraqui \& U. Veersma (eds.), Models of employee participation in a changing global environment : diversity and interaction (pp. 272-283). Ashgate: Aldershot.

Müller-Jentsch, W. (2008). Industrial Democracy: Historical development and current changes. Management Revue, 19, 260-273.

Nesheim, T. (2003). Using external work arrangements in core-value creation areas. European Management Journal, 21, 528-537.

Nienhüser, W., \& Matiaske, W. (2006). Effects of the 'principle of non-discrimination' on temporary agency work in 15 European countries. Industrial Relations Journal, 37, 64-77.

Nikolaou, I., Vakola, M., \& Bourantas, D. (2008). Who speaks up at work? Dispositional influences on employees' voice behavior. Personnel Review, 37, 666-679.

Pavitt, K. (1991). Key characteristics of the large innovating firm. British Journal of Management, 2, 41-50.

Pearce, J.L. (1993). Toward an organizational behavior of contract laborers: their psychological contract and effect on co-workers. Academy of Management Journal, 36, 1082-1096.

Pernicka, S. (2006). Organizing the self-employed: Theoretical considerations and empirical findings. European Journal of Industrial Relations, 12, 125-142.

Pernicka, S., \& Aust, A. (2007) (eds.). Die Unorganisierten gewinnen. Gewerkschaftliche Rekrutierung und Interessenvertretung atypisch Beschäftigter - ein deutsch-österreichischer Vergleich. Berlin: Edition Sigma.

Purcell, J., \& Georgiadis, K. (2006). Why should employers bother with worker voice? In R. Freeman, P. Boxall \& P. Haynes, (eds.), What workers say: employment voice in the Anglo-American world (pp. 181-197). Ithaca, NY: Cornell University Press.

Pyman, A., Holland, P., Teicher, J., \& Cooper, B.K. (2010). Industrial relations climate, employee voice and managerial attitudes to unions: An Australian study. British Journal of Industrial Relations, 48, 460480.

Ramsay, H. (1991). Reinventing the wheel? A review of the development and performance of employee involvement. Human Resource Management Journal, 1, 1-22.

Rousseau, D.M. (1995). Psychological contracts in organizations: Understanding written and un-written agreements, Newbury Park, CA: Sage.

Salis, S., \& Williams, A.M. (2010). Knowledge-sharing through face-to-face communication and labour productivity: Evidence from British workplaces. British Journal of Industrial Relations, 48, 436-459.

Schuler, R., \& Jackson, S. (1987). Linking competitive strategies with human resource management practices. Academy of Management Executive, 1, 207-219.

Schwarz-Kocher, M., Kirner, E., Dispan, J., Jäger, A., Richter, U., Seibold, B., \& Weißfloch, U. (2011). Interessenvertretungen im Innovationsprozess. Berlin: Edition Sigma. 
Storey, J., Quintas, P., Taylor, P., \& Fowle, W. (2002). Flexible employment contracts and their implications for product and process innovation. International Journal of Human Resource Management, 13, 1-18.

Stracke, S., \& Nerdinger, F.W. (2010). Mitbestimmung und Innovation aus Betriebsratsperspektive. Ergebnisse qualitativer Studien. Industrielle Beriebungen, 17, 30-53.

Streeck, W. (2001). The transformation of corporate organization in Western Europe: an overview. Cologne: Max Planck Institute for the Study of Societies.

Strömer, S. (2010). Individual characteristics of works council members - Empirical evidence. Management Revue, 21, 244-262.

Torka, N. (2003). Flexible but committed. On the relationship between contract and commitment. Enschede: Twente University Press.

Torka, N. (2011). Agency workers and Organisations' Commitment to its Workers (OCW). International Journal of Human Resource Management, 22, 1570-1585.

Torka, N., \& Schyns, B. (2007). On the transferability of 'traditional' satisfaction theory to non-traditional employment relationships: temp agency work satisfaction. Employee Relations, 29, 440-457.

Torka, N., \& Schyns, B. (2010). On equal job and co-worker commitment of agency workers and permanent employees: The role of HR practices. International Journal of Human Resource Management, 21, 1307-1322.

Torka, N., Schyns, B., \& Looise, J.C. (2010). Direct participation quality and organisational commitment: The role of Leader-Member Exchange. Employee Relations, 32, 418-434.

Torka, N., Van Woerkom, M., \& Looise, J.C. (2008). Direct Employee Involvement Quality (DEIQ). Creativity and Innovation Management, 17, 147-154.

Tsui, A., Pearce, J., Porter, L., \& Tripoli, A. (1997). Alternative approaches to the employee-organization relationship: Does investment in employees pay off? Academy of Management Journal, 40, 1089-1121.

Tsui, A., \& Wu, J. (2005). The "new employment relationship" versus the "mutual investment" approach: Implications for human resource management. Human Resource Management, 44, 115-121.

Van Breugel, G., Olffen, W., \& Olie, R. (2005). Temporary liaisons: The commitment of 'temps' towards their agencies. Journal of Management Studies, 42, 539-566.

Van het Kaar, R., \& Looise, J.C. (1999). De volwassen OR. Groei en grenzen van de Nederlandse ondernemingsraad. Alphen aan den Rijn: Samson.

Wallace, J.E. (1997). Becker's side-bet theory of commitment revisited: is it time for a moratorium or a resurrection?, Human Relations, 50, 727-749.

Zhou, H., Dekker, R., \& Kleinknecht, A. (2011). Flexible labor and innovation performance: evidence from longitudinal firm-level data. Industrial and Corporate Change, 20, 1-28. 